\title{
INDOLE DERIVATIVES AS POTENTIAL ANTICANCER AGENTS: A REVIEW
}

\author{
HARSHITA SACHDEVA*, JAYA MATHUR AND ANJALI GULERIA
}

Department of Chemistry, University of Rajasthan, Jaipur-302004, Rajasthan, India.

\begin{abstract}
Heterocyclic moiety serve as perfect framework on which pharmacophores can be effectively attached to produce novel drugs. Among various heterocyclic compounds, nitrogen-based heterocycles have been extensively investigated as they constitute the core structures of numerous biologically relevant molecules and have been found to be active against different types of cancers. Due to the versatility of indole, it has been a highly "privileged motif" for the target-based design and development of anticancer agents. Moreover, it has been used as a synthon for the preparation of large number of bioactive heterocycles and paved a way to develop effective targets. This review article presents comprehensive overview of anticancer potentiality of diversely substituted indole derivatives including $1 \mathrm{H}$-indole-2,3dione and Spiro indole derivatives.
\end{abstract}

Keywords: Heterocyclic compounds, Nitrogen-based, Indole, Spiro-indole, Anticancer agents.

\section{INTRODUCTION}

Heterocyclic compounds have paid enormously to the society in the form of large number of drugs for the treatment of various ailments and have occupied a prominent place in medicinal chemistry due to their varied biological activities [1-5]. Owing to their specific chemical reactivity, they constitute $80 \%$ of the drugs which are in therapeutic use. Majority of the large number of marketed drugs viz., chlordiazepoxide (tranquillizer)[6], imipramine (antidepressant)[7], guanethidine (antihypertensive)[8], indapamide (diuretic and antihypertensive) $[9,10]$, etc. are heterocyclic compounds and many antibiotics including penicillin, cephalosporin, norfloxacin, streptomycin etc., also contain heterocyclic ring[11-14]. Cancer is the major cause of death worldwide. Current cancer treatment possibilities include surgery, chemotherapy, and radiation therapy or a combination of these options [15]. Since past few decades, many heterocyclic compounds have been recognized as potential anticancer agents [16, 17]. Around $60 \%$ of the medications used for cancer treatment are based on heterocyclic moieties [18]. Although recommended quantity of anticancer drug is adequate to kill cancer cells but is generally harmful to the normal tissue and lead to many side effects, which restricts its treatment efficacy [15]. Hence, scientists are searching new anticancer drugs by designing and exploring new compounds for the treatment of various types of cancers which are devoid of side effects caused by conventional antineoplastic drugs.

Indole core has been continuously attracting the attention of researchers and has become a dynamic area of research due to its outstanding pharmacological properties [19-21]. It is designated as "privileged scaffolds" which bind to multiple receptors with high affinity, leading to the development of novel bioactive drugs [22-25]. It is used for the target-based design and development of anticancer agents [26]. In this context, therapeutic effect of multi-target directed indole based hybrid molecules in cancer therapy is recently reviewed by Sunil et al [27].

Indole core is widely distributed in the nature [28] and is present in many important alkaloids viz. auxins [29] and tryptophan [30]. The indole moiety is related to the neurotransmitter serotonin implicated for brain function and cognition as the endogenous receptor agonist [31]. Indole alkaloids, vallesiachotamine and iso-vallesiachotamine isolated from the fruits of Anthocephalus cadamba(Family: Rubiaceae) are found to exhibit potent anticancer activity[32] and indole alkaloids from marine natural products show numerous biological activity, including cytotoxic, antiviral, antimicrobial, antiparasitic, anti-inflammatory, antiserotonin, $\mathrm{Ca}^{2+}$, calmodulin-antagonistic activity and antitopoisomerase-I activity, along with in vivo activity [33, 34]. Reserpine, an indole alkaloid, is used to treat high blood pressure and severe agitation in patients with mental disorders [35]. Compounds which contain cyclohepta[b] indoles possess broad spectrum of biological activities including inhibition of adipocyte fatty-acid-binding protein (A-FABP), deacetylation of histones, inhibition of leukotriene production p53, antituberculosis activities, and anti-HIV activities [36]. Monoterpenoid indole alkaloid from Melodinus khasianus [37] possess anticancer activity and from the African medicinal plant Tabernaemontana elegans serves as lead for targeting multidrug resistant cancer cells [38]. Dimeric monoterpene indole alkaloids, vincristine and vinblastine are used for the treatment of several types of cancers, including Hodgkin's disease, Kaposi's sarcoma, non-Hodgkin's lymphoma, and breast or testicle cancer $[39,40]$.

Indole derivatives have been extensively used as synthons for the preparation of large number of biologically relevant heterocycles [41](Chart 1). Moreover, indoles are found in important synthetic drug molecules with interesting pharmacological properties like SARS coronavirus 3CL protease inhibitors [42], anti-HIV activity [43], antituberculosis activity [44], anticonvulsant [45] and HIV-TB coinfection [46] including anti-cancer [47]. Indoles are also associated with the inhibition of $\mathrm{NFkB} / \mathrm{mTOR} / \mathrm{PI} 3 \mathrm{~K} / \mathrm{AkT}$ and regulation of estrogenmediated activity [48]. Several 3-substituted indole derivatives have been found to exhibit remarkable antineoplastic properties viz. inhibition of cell proliferation of human colon carcinoma (HT-29), human ovarian adenocarcinoma (SK-OV3), and c-Src kinase activity [49]. Significantly, 3-pyranyl indoles have showed good anticancer activity against MCF-7 breast cancer cell lines in comparison with standards drugs [50].

Further, $(E)$-3-(5-substituted-1 $H$-indol-3-yl)-1-(5,5,8,8-tetramethyl-5,6,7,8tetrahydronaphthalen-2-yl) prop-2-en-1-one derivatives have anti-proliferative capacity in liver, breast and colon cancer cell lines [51] and indole-3-carbinol, bis(3'-indolyl) methane and synthetic analogs are associated with cancer chemotherapy as reported by Safe et al. [52] Furthermore, indole-3-carbinol and its metabolite 3,3'-diindoylmethane (DIM) target multiple aspects of cancer cellcycle regulation and survival including Akt-NFKB signaling, caspase activation, cyclin-dependent kinase activities, estrogen metabolism, estrogen receptor signaling, endoplasmic reticulum stress, and BRCA gene expression [53]. This broad spectrum of anti-tumor activities in conjunction with low toxicity highlights the translational value of indole-3-carbinol and its metabolites in cancer prevention/therapy [53]. Anti-carcinogenic and anti-metastatic properties of indole-3-carbinol in prostate cancer has been reported by Garikapaty et al [54]. Several aroylindoles, arylthioindoles, diarylindoles and indolylglyoxyamides have shown good inhibition towards the tubulin polymerization [55]. Encouraged by the excellent and promising anticancer activities of indole derivatives and keeping in view of the several studies reported recently by the researchers altogether, it was thought to collect the literature consisting of new indole derivatives as potential anticancer agents. 

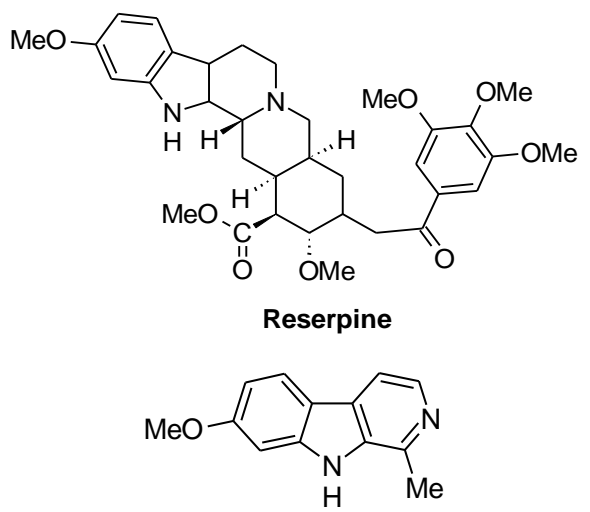

Harmine

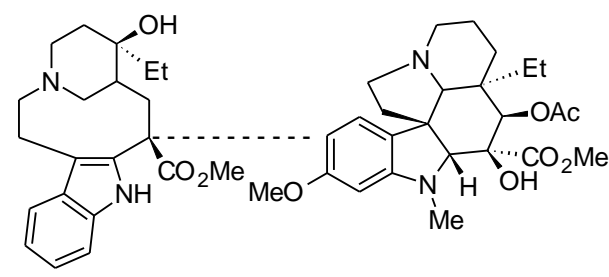

Vincristine<smiles>CCNC(=O)C1CC2c3cccc4[nH]cc(c34)CC2N(C)C1</smiles>

L.S.D.

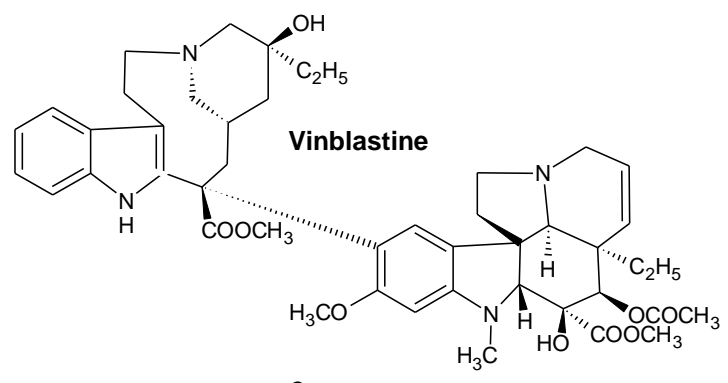<smiles>Cn1c(/C=C/CO)c(CO)c2c1C(=O)C=C(N1CC1)C2=O</smiles>
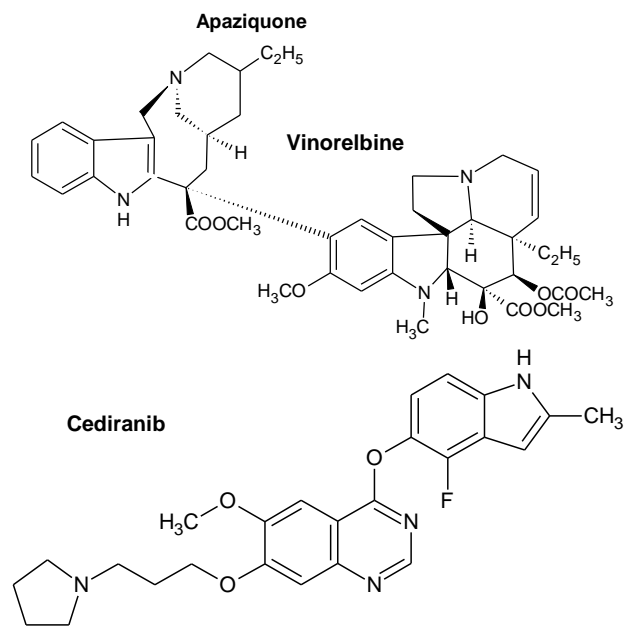

Chart 1: Indole ring containing anti-cancer drugs
The present review article reflects overview of anticancer potentiality of variously substituted indole derivatives mainly N1-, C-2, C-3, C-5 substituted indoles, $1 \mathrm{H}$-indole-2,3-dione (isatin) derivatives and Spiro indole derivatives that can be employed as a valuable support towards more potent drugs.

\section{Anticancer activity of indole derivatives}

Andreani et al [56] prepared and tested 3-indolylmethylene-2-indolinone derivatives for antitumor activities. Synthesized compounds were similar to 3(2-chloro-3-indolylmethylene)1,3-dihydroindol-2-ones but with the two indole systems separated by an heterocycle (pyridine or piperazine) instead of a methine bridge and were evaluated for antitumor activity in the human cell line screen. The pyridine derivatives (compound 1) were far more active than the piperazine derivatives (compounds 2, 3, 4). Interesting results were obtained with halogens, methoxy and dimethylamino groups. The compound containing chlorine at the 4 position of the indole (compound $\mathbf{1}, \mathbf{R}^{\mathbf{1}}=\mathbf{C l}$ ) was very active: the activity decreased by shifting the halogen from the 4 to the 5 (compound $\mathbf{1}, \mathbf{R}^{2}=\mathbf{C l}$ ) and 6 position (compound $\mathbf{1}, \mathbf{R}^{\mathbf{3}}=\mathbf{C l}$ ). The compound bearing the 5-methoxy-2indolinone moiety was subjected to the first in vivo experiment (hollow fiber assay) and was found to be active.

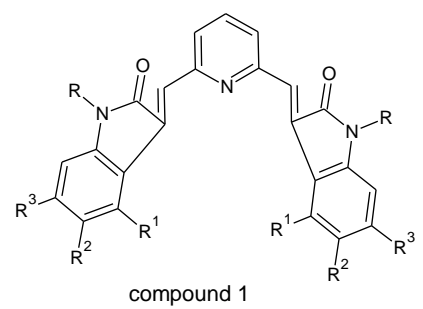

3,3'-[pyridine-2,6-diylbis(methylene)]bis(1,3-dihydroindol-2-ones)<smiles>[R]c1ccc2c(c1)C(=c1[nH]c(=O)/c(=C3\C(=O)Nc4ccc([R])cc43)[nH]c1=O)C(=O)N2</smiles>

\section{3,6-bis(2-oxo-1,2-dihydroindol-3-ylidene)piperazine-2,5-diones}

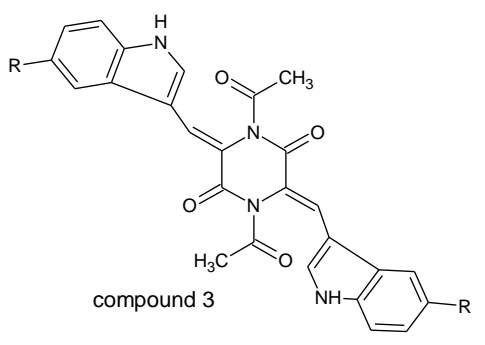

1,4-diacetyl-3,6-bis(indol-3-ylmethylene)piperazine-2,5-diones<smiles>[R]c1ccc2c(c1)/C(=c1/[nH]c(=O)/c(=C3/CNc4ccc([R])cc43)[nH]c1=O)NC2</smiles>

\section{3,6-bis(indol-3-ylmethylene)piperazine-2,5-diones}

Bis-indolinone derivatives having either 2,6-disubstituted pyridine core or 1,10-disubstituted phenanthroline core have been tested as potential Gquadruplex binders by Amato et al [57]. Sharma et al [58] carried out reaction of $C$-(3-indolyl)- $N$-phenylnitrone with allenic esters under mono-mode microwave irradiation to afford via a domino process, bis-indole derivatives (compounds, $\mathbf{5}$ 
\& 6) which were evaluated against various human cancer cell lines [58] such as cancer of the breast (MCF-7), ovary (IGROV-1), lung (A-549, HOP-62) and colon (HCT-15 and SW-620) and were mainly found to be active against colon (HCT-15, SW-620) cancer cells. Compound 5 showed inhibition of $61 \%$ at $100 \mu \mathrm{M}$ and $58 \%$ at $50 \mu \mathrm{M}$ against colon cell line (SW-620) with $\mathrm{IC}_{50}$ of $39.7 \mu \mathrm{M}$. Compound 6 showed inhibition of $75 \%$ at $100 \mu \mathrm{M}$ and $46 \%$ at $50 \mu \mathrm{M}$ against colon cell line (SW-620) with $\mathrm{IC}_{50}$ of $39.7 \mu \mathrm{M} ; 85 \%$ at $100 \mu \mathrm{M}$ and $56 \%$ at $50 \mu \mathrm{M}$ against colon cell line (HCT-15) with $\mathrm{IC}_{50}$ of $46.6 \mu \mathrm{M}$.<smiles>CCOC(=O)/C=C/c1c[nH]c2ccccc12</smiles>

compound 5 compound 6

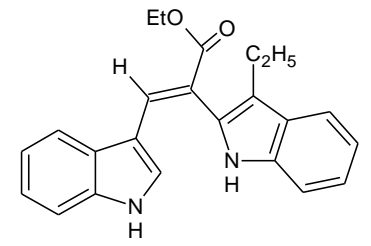

Zhuang et al [59] synthesized and evaluated a series of 2,4-disubstituted furo[3,2- $b]$ indole derivatives for anticancer potentiality and established the structure-activity relationships (SARs) of these compounds. Among the tested compounds, (5-((2-(hydroxymethyl)-4H-furo[3,2-b]indol-4-yl)methyl) furan-2-yl)methanol (Compound 7) was found to exhibit highly selective anticancer activity against NCI-60 human tumor cell lines and significant inhibitory activity against A498 renal cancer cells.
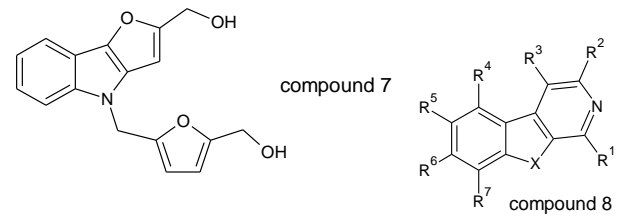

$$
\begin{aligned}
& \mathrm{R}^{1}=\text { Aryl, substituted aryl, } \\
& \text { Heteroaryl } \\
& \mathrm{R}^{2}=\text { COOEt, } \mathrm{R}^{3}=\mathrm{Ph} \\
& \mathrm{R}^{4}=\mathrm{H} \\
& \mathrm{R}^{5}=\mathrm{OCH}_{3}, \mathrm{OCH}_{2} \mathrm{Ph}, \mathrm{Cl}, \mathrm{Br} \\
& \mathrm{CH}_{2} \mathrm{SO}_{2} \mathrm{NHCH}_{3}, \mathrm{OCF}_{3}, \mathrm{CN}, \mathrm{H} \\
& \mathrm{R}^{6}=\mathrm{OCH}_{3}, \mathrm{H} \text {, } \\
& \mathrm{R}^{7}=\mathrm{CH}_{3}, \mathrm{OCH}_{3}, \mathrm{H} \\
& \mathrm{X}=\mathrm{NH}, \mathrm{NCH}_{3}, \mathrm{O}, \mathrm{S}
\end{aligned}
$$

Patil et al [60] synthesized and tested series of pyrido[3,4-b]indoles (compound 8) for their antiproliferative activity against human cancer cell lines, comprising HCT116 colon, HPAC, MIA PaCa-2 and Panc-1 pancreatic, MCF-7 and MDA-MB-468 breast, A375 and WM164 melanoma, A549 lung, and LNCaP, DU145 and PC3 prostate cancer lines. Pyrido[3,4-b]indoles displayed SAR with respect to antiproliferative activity. 1-Naphthyl at $\mathrm{C} 1$ combined with methoxy at C6 (compound-1-naphthyl-6-methoxy-9H-pyrido [3,4-b]indole) provided the best antiproliferative activity hence the highest potency. Ali et al [61] synthesized micellar "nano" indole heterocyclic "anti-cancer compounds", DNA binding studies of synthesized molecules carried out and DNA binding constants were also calculated. The activities of the developed nano anticancer drugs were tested on HepG2 (C3A) cell lines. It was observed that compound 9 $\left(\mathrm{R}=\mathrm{NO}_{2}, 4-\mathrm{Br}, 2-\mathrm{OMe}\right)$ and compound $\mathbf{1 0}\left(\mathrm{R}=4-\mathrm{NO}_{2}\right)$ at a micellar concentration of $670 \mu \mathrm{L} \mathrm{mL}^{-1}$ displayed excellent anticancer activities against the HepG2/C3A line $(25-50 \%)$. The potency of nano anticancer drugs was predicted by drug likeness using Lipinski's "rule of five". Compounds 9 \& 10 followed Lipinski's rule of five and could be used to treat cancers.
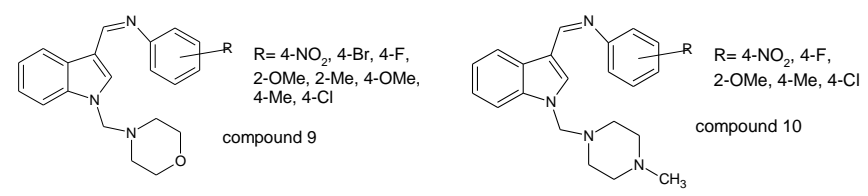

Kamel et al [62] reported synthesis of bio isosteres of marine indole alkaloids, Compound 11 (meridianins) and anti-proliferative activity against HCT-116 cell line. The 2-aminopyrimidine ring of meridianins was replaced with 5aminopyrazole, pyrazolo[1,5-a]pyrimidine and pyrazolo[3,4-b]pyridine rings. The cytotoxic screening revealed that pyrazolo[1,5-a]pyrimidines (compounds 12 and 13) had the most potent cytotoxic activity with IC $50=0.31 \mu \mathrm{M}$ and 0.34 $\mu \mathrm{M}$ respectively. Compounds 12 and 13 were also investigated for their kinase inhibitory potencies toward six kinases (CDK5/p25, CK1ð/ $\varepsilon$, GSK-3 $\alpha / \beta$, Dyrk1A, Erk2, and CLK1). They exhibited effective inhibition of GSK-3 $\alpha / \beta$ (IC50 $=0.196 \mu \mathrm{M}$ and $0.246 \mu \mathrm{M}$, respectively) and Erk2 (IC50 $=0.295 \mu \mathrm{M}$ and $0.376 \mu \mathrm{M}$, respectively). 2-Aminopyrimidinyl ring of meridianins was replaced with pyrazolo[1,5-a]pyrimidine and pyrazolo[3,4-b]pyridine rings which showed promising cytotoxic activity compared to the five membered 5-aminopyrazole.<smiles>Nc1nccc(-c2c[nH]c3ccccc23)n1</smiles><smiles>Ic1ccc(-c2cc(-c3ccc([123I])cc3)nc3cc(-c4c[nH]c5ccccc45)nn23)cc1</smiles>
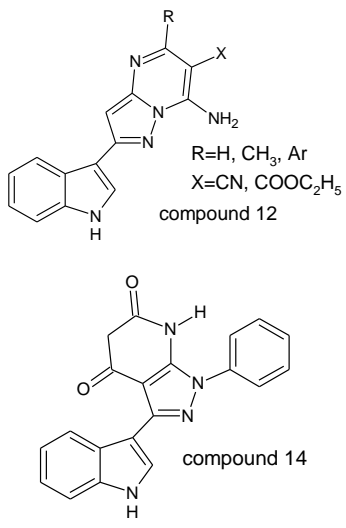

Cascioferro et al [63] synthesized and studied indole-based imidazo[2,1$b][1,3,4]$ thiadiazole derivatives (Compound 15) for their in vitro antiproliferative activity on a panel of pancreatic ductal adenocarcinoma (PDAC) cells, including SUIT-2, Capan-1 and Panc-1. Compounds 15a $\left(\mathbf{R}=\mathbf{O C H}_{\mathbf{3}}, \mathbf{R}^{\mathbf{1}}=\mathbf{H}, \mathbf{R}^{\mathbf{2}}=\mathbf{4}-\mathbf{N O}_{2}\right)$ and $\mathbf{1 5 b}\left(\mathbf{R}=\mathbf{F}, \mathbf{R}^{1}=\mathbf{H}, \mathbf{R}^{2}=\mathbf{H}\right)$, showed relevant in vitro antiproliferative activity on all three pre-clinical models with half maximal inhibitory concentration $\left(\mathrm{IC}_{50}\right)$ ranging from 5.11 to $10.8 \mu \mathrm{M}$. In addition, compound 15a significantly inhibited the migration rate of SUIT-2 and Capan-1 cells in the scratch wound-healing assay.

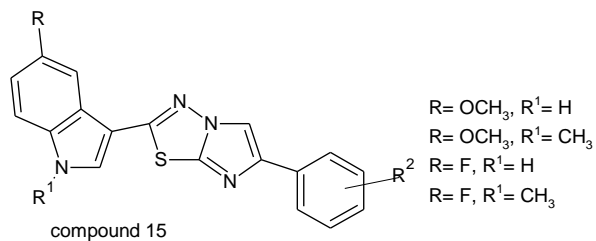

Kaur et al [64] synthesized a series of indole hybridized diazenyl derivatives efficiently by condensation of diazotized p-aminoacetophenone with indole or nitroindole followed by reaction with different aromatic/heteroaromatic amines of biological significance and evaluated for cytotoxicity against human lung carcinoma cell line (HCT-116), breast cancer cell line (MDAMB231), leukemic cancer cell line (K562), and normal cell line (HEK293) by MTT assay using doxorubicin as the standard drug. The indole hybridized diazenyl derivatives, Compound $16\left(\mathrm{X}=\mathrm{Y}=\mathrm{R}=\mathrm{R}^{2}=\mathrm{H}, \mathrm{R}^{1}=4-\mathrm{COOH}\right)$ and compound 17 were found to be active against breast cancer cell line and human colon carcinoma cell line having $\mathrm{IC}_{50}$ in the range of $19-65 \mu \mathrm{g} / \mathrm{ml}$.
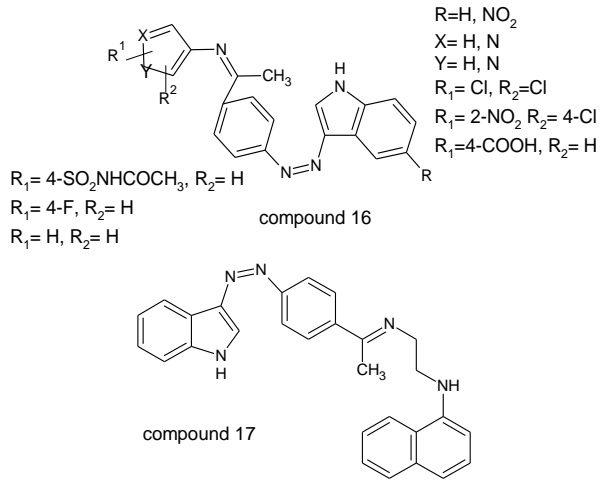

\section{H-indole-2,3-dione derivatives}

Among indole derivatives, $1 H$-indole-2, 3-dione (Isatin) has received considerable attention due to its potent biological activities [65-69] such as antioxidant, anti-inflammatory, antimicrobial, antituberculosis, anticancer, antiHIV, antiviral, and anticonvulsant, etc. It was first obtained by Erdman [70] and Laurent [71] in 1840 as a product from the oxidation of indigo dye by nitric acid and chromic acids. The synthetic versatility of $1 \mathrm{H}$-indole-2,3-dione has led to the extensive use of this compound in organic synthesis. In nature, It is found in plants of the genus Isatis, in Calanthe discolor LINDL. It is the biologically 
active chemical produced by an Altermones sp. strain inhibiting the surface of embryos of the cardiean shrimp Palaemon macrodectylus, which protect them from the pathogenic fungus Lagenidium callinectes [72]. It undergoes several types of reactions due to the presence of several reaction centres Thus, keto group at position 2 and particularly, at position 3 can enter into addition at the Cbond and into condensation with release of the water molecule. Compounds of the $1 \mathrm{H}$-indole-2,3-dione series are capable of entering into $\mathrm{N}$-alkylation and $\mathrm{N}$ acylation and into the Mannich and Michael reactions [73] through the NH group. Their Schiff bases and Mannich bases are known to possess a wide range of pharmacological properties including antibacterial (Pandeya et al [74]; Sarangapani and Reddy [75]; Varma and Nobles [76]), anticonvulsant (Sridhar et al [77]; Varma et al [78]), anti-HIV (Pandeya et al [79, 80]; Sriram et al [81]), antiviral (Singh et al [82]), and anticancer activity (Karki et al [83, 84]). Many fluorinated $1 \mathrm{H}$-indole-2,3-dione derivatives like 1-dialkylaminoacetyl-5/6fluoroindole-2,3-diones, 2-([2-(fluoroaryl)- $1 H$-indol-3-yl]methylene) hydrazine carbothioamides and 2-(fluoroaryl)-([5-(substituted benzylidene)4-oxo-2-thiazolidinylidene]hydrazone)- $1 H$-indole-3-carboxaldehydes possess antibacterial activity [85] and antifertility activity [86]. Jain et al [87] synthesized derivatives of 5-fluoroisatin with ethyl cyanoacetate and substituted ketones which show anticonvulsant activity.

\section{Anticancer activity of $\mathbf{1 H}$-indole-2, 3-dione derivatives}

Vine et al [88] synthesized a range of substituted $1 H$-indole-2,3-diones (isatins) and studied their cytotoxicity against the human monocyte-like histiocytic lymphoma (U937) cell line in vitro. SAR studies indicated $\mathrm{C}_{5}, \mathrm{C}_{6}$, and $\mathrm{C}_{7}$ substitution greatly enhanced activity with some di- and tri-halogenated isatins giving $\mathrm{IC}_{50}$ values $<10 \mu \mathrm{M}$. These compounds showed greater selectivity toward leukemia and lymphoma cells over breast, prostate, and colorectal carcinoma cell lines. The most active compound, 5, 6, 7-tribromoisatin (compound 18), was found to be antiproliferative at low micromolar concentrations and also activated the effector caspases 3 and 7 in a dosedependent manner. These results indicate that di- and tri-substituted isatins may be useful leads for anticancer drug development in the future [88].

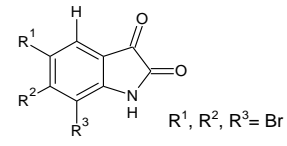

compound 18

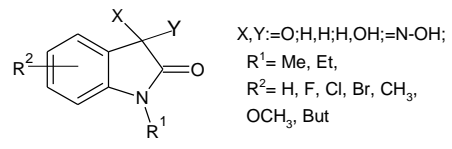

compound 19

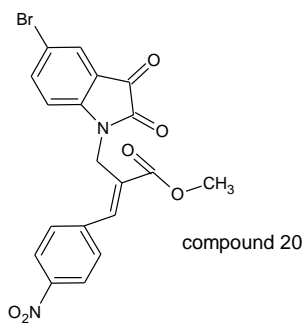

A series of di- or trisubstituted isatin derivatives were synthesized (compound 19) and evaluated for anticancer activity against human $T$ lymphocyte cells Jurkat by Teng et al [89]. SAR study suggested that the combination of 1-benzyl and 5-[trans-2-(methoxycarbonyl)ethen-1-yl] substitution greatly enhanced their cytotoxic activity. Baylis-Hillman adduct-derived $N$-cinnamyl-substituted isatin derivatives were synthesized and evaluated for their anticancer activity against four different cell lines Chinese hamster ovary (CHO cells), Colo 205 (human colon cancer), Sup-T1 (human lymphoma) and C6 glioma (rat glioma) by MTT assay method by Kumar et al [90]. The compound 20 has shown specific cytotoxic activity. Gudipati et al [91] synthesized a series of 5 or 7 substituted 3-\{4-(5-mercapto-1,3,4-oxadiazol-2-yl)phenylimino $\}$-indolin-2-one derivatives, compound 21 and studied for their anticancer activity against HeLa cancer cell lines using MTT assay. All the synthetic compounds produced a dose dependent inhibition of growth of the cells. The $\mathrm{IC}_{50}$ values of all the synthetic test compounds were found between 10.64 and $33.62 \mu \mathrm{M}$. Among the synthesized 2indolinones, compound 21 with halogen atom (electron withdrawing groups, F, $\mathrm{Cl}, \mathrm{Br}$ ) at $\mathrm{C} 5$ position showed the most potent activity. Kamal et al [92] synthesized and evaluated 3,3-diindolyl oxyindole derivatives against a panel of five human cancer lines and most of them showed potent cytotoxicity (compound 22).

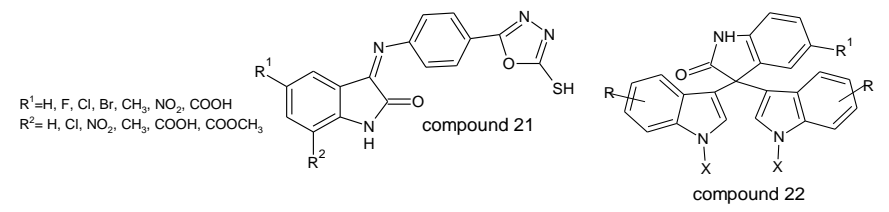

A series of isatin-based heterocyclic compounds were synthesized (compounds 23 \& 24) by the condensation of commercially available, active methylene heterocycles with isatin in moderate to excellent yields and found to inhibit proliferation of cancer cell lines resistant to apoptosis by Evdokimov et al [93].

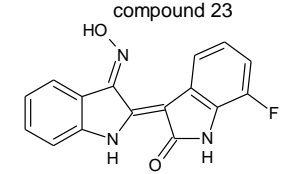

OE21 esophageal cancer apoptosis-resistant cancer cell lines

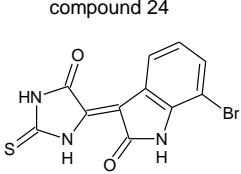

U373 glioblastoma
A series of 4/3-((4-oxo-5-(2-oxoindolin-3-ylidene) thiazolidin-2ylidene)amino) benzenesulfonamides were synthesized by Eldehna et al [94] and evaluated for their anti-proliferative activity against breast cancer MCF-7 and colorectal cancer Caco-2 cell lines. Compound 25 was found to be the most potent derivative against $\mathrm{MCF}-7 \quad\left(\mathrm{IC}_{50}=3.96 \pm 0.21 \mu \mathrm{M}\right)$, Compound 25 induced the intrinsic apoptotic mitochondrial pathway in MCF-7 cells; evidenced by the enhanced expression of the pro-apoptotic protein Bax and the reduced expression of the anti-apoptotic protein Bcl-2, and the up-regulated active caspase-9 and caspase-3 levels [94].

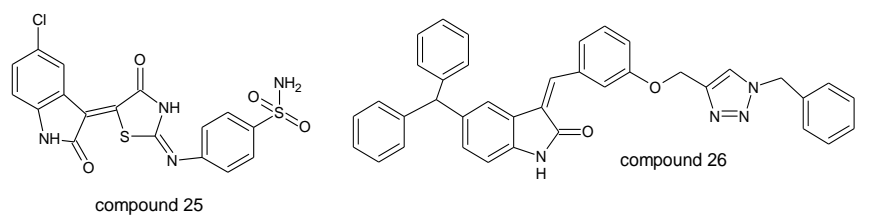

A series of triazole linked 3-benzylidene isatin hybrids were synthesized and assessed against DU145 (prostate), PC-3 (prostate), MDA-MB-231 (breast), BT549 (breast), A549 (lung) and HeLa (cervical) human cancer cell lines by employing MTT assay for their cytotoxic potential by Nagarsenkar et al [95]. Compound 26 was found to be most potent amongst all the tested compounds with an $\mathrm{IC}_{50}$ value of $(3.7 \pm 0.05 \mu \mathrm{M})$ on DU145 cells and Compound 26 can induce cell apoptosis in DU145 cells [95]. Moreover, 3-hydrazinoindolin-2-one derivative of isatin, represents a pharmacophore with potential anticancer activities and is extensively reviewed [96].

A sequence of isatin derivatives of podophyllotoxin were synthesized by Zhang et al [97] and evaluated for their cytotoxic activity against human leukemia K562 cells and adriamycin-resistant K562/ADR cells using CCK-8 assay in vitro. Among them, the cytotoxicities exhibited by compounds $27 \mathbf{a}$ and 27b were found to be comparable or more effective than podophyllotoxin. In particular, 27a exhibited significant cytotoxicity against resistance K562/ADR cells with $\mathrm{IC}_{50}$ value of $0.067 \pm 0.010 \mu \mathrm{M}$. Furthermore, cell cycle analysis revealed that 27 a could remarkably induce K562/ADR cell cycle arrest in the G2/M phase [97].
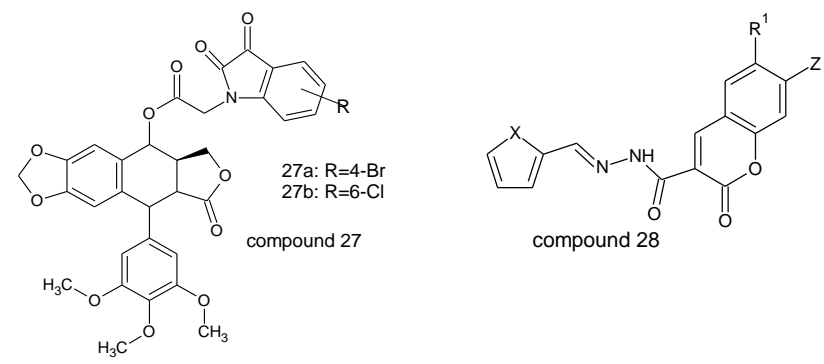

compound 28

Nasr et al [98] synthesized sixteen coumarins bearing hydrazide-hydrazone moiety (compound 28) and evaluated them against human drug-resistant 
pancreatic carcinoma (Panc-1) cells and drug-sensitive (hepatic carcinoma; HepG2 and leukemia; CCRF) cell lines in vitro. Bromocoumarins were found to be the most active antitumor agent against drug-resistant pancreatic carcinoma cells [98]. Similarly, Kakkar et al recently reviewed anticancer activities of diversely substituted isatin derivatives [99].

\section{Spiro-indole derivatives}

Furthermore, indole substituted with heterocyclic rings at the 3-position have been found in a fascinating array of bioactive natural products and pharmaceutical compounds [100]. It was found that several alkaloids and compounds obtained from marine molluscs and shell fish are heterocyclic compounds having a Spiro system at the position 3- of the 2-indolinone skeleton [101]. Spiro-indoles, with C-3 as Spiro atom act as precursors for the synthesis of novel heterocyclic systems and have received considerable attention as all sorts of rings beginning from one ring system to three ring systems with heteroatom can be incorporated by cyclization and rearrangement reactions [100]. Further, the other ring incorporated at C-3 of indole ring can have wide variation. This gives tremendous scope for the synthesis of novel pharmacodynamic indole heterocycles. Moreover, Spirooxindole derivatives occupy a special place in organic and medicinal chemistry because these compounds are well-known as microtubule assembly inhibitors (spirotryprostatin A and B)[102], Muscarinic M1, and serotonin receptor modulators (pteropodine and isopteropodine) [103] and nonpeptidyl growthhormone secretagogues (MK-0677) [104]. Fredricamycin A, a Spiro heterocycle is an antitumor antibiotic agent [105]. Considerable attention has been paid on the development of new strategies to synthesize many kinds of Spiro oxindole ring systems because of their interesting biological and pharmacological properties, such as vasodilatory, hypoglycaemic, anti-inflammatory, antimicrobial, analgesic, and antipyretic activities [106, 107]. Several articles regarding anticancer activity of Spiro indole derivatives have been published during last decade [108, 109]. Owing to exclusive above-mentioned structural features and numerous biological activities associated with Spiro indole derivatives, they perform major and dynamic role in drug design and discovery (Chart 2).
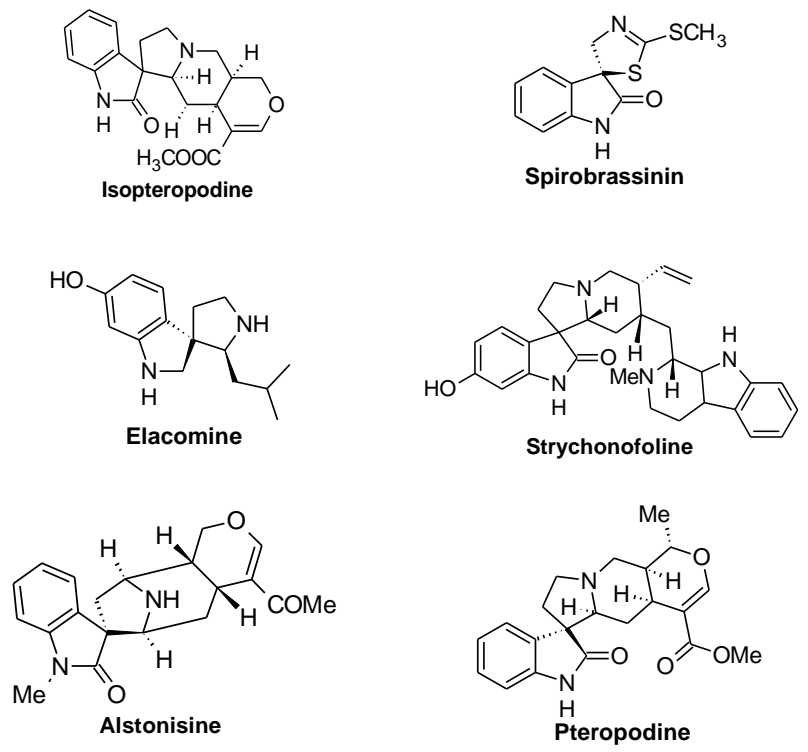

Chart 2: Biologically active Spiro indole derivatives.

\section{Anticancer activity of Spiro-indole derivatives}

Synthesis and evaluation of the anticancer activity of 3'-aryl-5'- arylidenespiro [3H-indole-3, ''-thiazolidine]-2,4' $(1 H)$-diones and spiro [3H-indole-3,2'thiazolidine] -2,4'(1H)-dione-3'-alkanoic acid esters was described by Kaminskyy et al [110]. Among the tested compounds, (5'Z)-5'-(benzylidene) -3'(4-chlorophenyl) spiro[3H-indole -3,2'- thiazolidine] -2,4'(1H)-dione (29a) and (5'Z)-3'-(4-chlorophenyl)-5'-[4- (1-methylethyl) -benzylidene]spiro[3H-indole3,2'-thiazolidine]-2,4'(1H)-dione (29b) were superior to other related compounds and may be considered due to the presence of 4-thiazolidinone group[110].

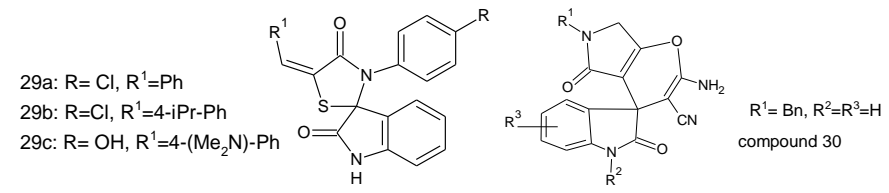

A simple and efficient protocol for assembling novel Spiro[indolepyranopyrrole] derivatives (compound 30) was developed and used to prepare a series of biologically important compounds by Han et al [111]. The cytotoxic activities of Spiro[indole-pyranopyrrole] derivatives were evaluated in vitro and found to exhibit significant cytotoxicities to Raji cell lines.

Synthesis, characterization and anticancer activity of Spiro[pyrrolidine-3,3'oxindole] derivatives, compounds 31 was carried out by Konyar et al [112]. Cytotoxic effects of the compounds were determined on Huh7, MV, HCT116 and MCF7 cancer cell lines by the NCI-60 Sulforhodamine B Assay, using (S)(+)-Camptothecin as a positive control. Generally, target compounds showed better cytotoxic activities against the MCF7 and HCT116 cancer cell lines. It was found that compound 31 exhibited the most potent inhibitory activity with IC50 values of $4.8 \mu \mathrm{M}, 3.9 \mu \mathrm{M}, 14.9 \mu \mathrm{M}$ and $8.2 \mu \mathrm{M}$ against the MCF7, HCT116, MV and Huh7 cell lines, respectively [112].

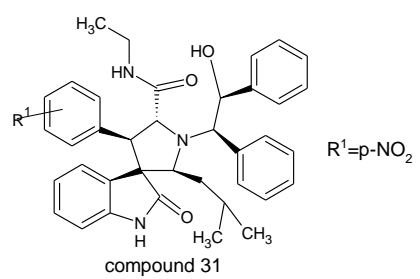

Yong et al [113] synthesized 3'-spirocyclic-oxindole compounds, based on the Spiro[indole-3,5'-isoxazolidin]-2(1H)-one, the $2^{\prime} H$-spiro [indole-3,6'[1,3]oxazinane] $-2,2^{\prime}(1 H)$-dione and the $2^{\prime} H$-spiro[indoline-3,3'-pyrrolo[1,2c] $\left[1,3^{\prime}\right]$ oxazine $]-1^{\prime}, 2(1 H)$-dione heterocyclic compounds (32-34). These compounds were prepared from methyl $\alpha$-(2-nitrophenyl)acrylate via $[1,3]$ dipolar cycloaddition reactions with two acyclic nitrones and one cyclic nitrone followed by reduction of the cycloadducts and then treatment with triphosgene. Two of these compounds showed significant cytostatic activity on three cancer cell lines with $\mathrm{GI}_{50}$ values of $2.6-4.1 \mu \mathrm{M}$ on the human breast cancer cell line, MCF-7.
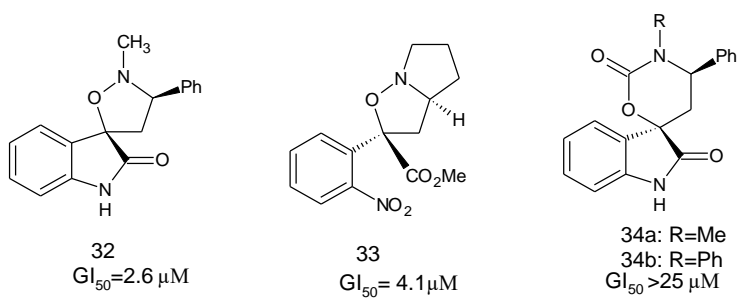

Barakat et al [114] investigated one-pot three-component reaction via a [3+2] cycloaddition/ring contraction sequence of a dipolarophile (activated alkene) with in situ-generated azomethine ylide (1,3-dipoles) without the use of any catalyst leading to the formation of biologically important spirooxindoles in high yield (69-94\%) with high diastereoselectivity. The synthesized compounds were subjected to cytotoxicity evaluation using colorectal cancer (HCT-116), hepatocellular carcinoma (HepG2), and prostate cancer (PC-3) cells. Compounds 35b, 35c, and 35d showed potent cytotoxic activity and high selectivity against HCT-116 cells compared to cisplatin. Further, compound 35a retained high cytotoxic activity and selectivity against HepG2 and PC-3 cells in comparison to cisplatin.

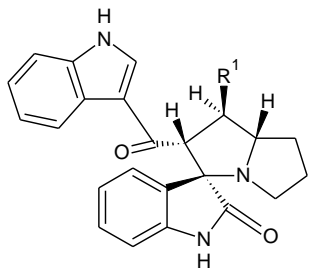

35a: $\mathrm{R}^{1}=2,4-\mathrm{Cl}_{2} \mathrm{C}_{6} \mathrm{H}_{3}$ 35b: $\mathrm{R}^{1}=\mathrm{m}-\mathrm{Me}-\mathrm{C}_{6} \mathrm{H}_{4}$ 35c: $\mathrm{R}^{1}=\mathrm{m}-\mathrm{Br}-\mathrm{C}_{6} \mathrm{H}_{4}$ 35d: $R^{1}=p-C F_{3}-C_{6} H_{4}$ 
A series of functionalized Spirooxindole linked with 3-acylindole scaffold is synthesized starting from chalcones derived from 3 -acetyl indole with isatin, and 1-4-thiazolidinecarboxylic acid by Islam et al [115] in high yield (71-89\%). The spirooxindole hybrids have been evaluated in vitro for their antiproliferative effects against colon cancer (HCT-116), hepatocellular carcinoma (HepG2) and prostate cancer (PC-3). Compound 36 proved to retain a high cytotoxic activity and selectivity against colon cancer cells HCT-116.
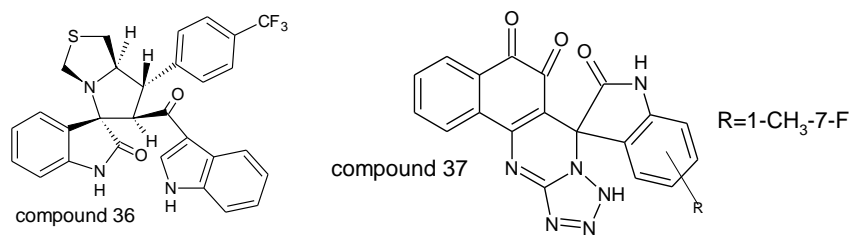

A series of Spiro oxindole- $O$-naphthoquinone-tetrazolo[1,5- $a$ ]pyrimidine hybrids were synthesized and evaluated as potent antitumor agents by $\mathrm{Wu}$ et al [116]. These hybrids exhibited relatively high cytotoxic activity against cancer cell line HepG2 $\left(\mathrm{IC}_{50}=2.86-36.34 \mu \mathrm{M}\right)$, while normal cell line $\mathrm{LO} 2$ was less sensitive to these hybrids $\left(\mathrm{IC}_{50}=36.37-248.39 \mu \mathrm{M}\right)$. Among all the compounds tested, compound 37, with a mean $\mathrm{IC}_{50}$ value of $2.86 \mu \mathrm{M}$, was the most active. Furthermore, Lotfy et al [117] synthesized a new series of heterocycles containing spirooxindole and pyrrolidine rings by the 1,3dipolar cycloaddition of an azomethine ylide, which was generated in situ by the condensation of a secondary amino acid (l-proline) and dicarbonyl compounds (isatin), with dipolarophiles and evaluated against breast cancer cell lines (MCF-7) and leukemia (K562). Among them, compound 38 was identified as the most potent with $\mathrm{IC}_{50}$ values of $15.49 \pm 0.04 \mu \mathrm{M}$, against breast cancer cell lines (MCF-7) compared to standard drug 5-Fu ( $\left.\mathrm{IC}_{50}=78.28 \pm 0.2 \mu \mathrm{M}\right)$.

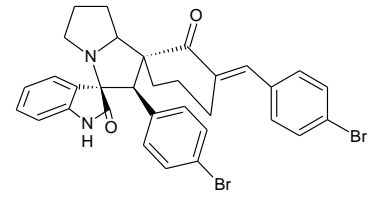

compound 38

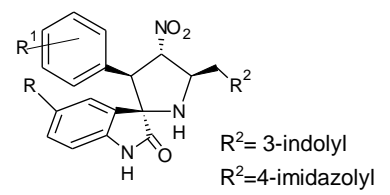

compound 39
Arumugam et al [118] reported synthesis of a small library of hybrid Spiro heterocycles containing Spiro oxindole, pyrrolidine and indole/imidazole moieties compound 39 with complete regio- and diastereoselectively from a three-component process starting from a series of variously substituted $(E)$-(2nitrovinyl)benzenes, indoline-2,3-dione derivatives and 1-tryptophan or 1histidine in an ionic liquid and evaluated for their anticancer activity. Compounds were shown to inhibit the proliferation of $\mathrm{FaDu}$ cells, a human epithelial cell line isolated from a squamous cell carcinoma of the hypopharynx, via apoptotic cell death. Eldehna et al [119] reported one-pot three-component synthesis of novel spirooxindoles (compound 40) and evaluated their potential anti-proliferative activity towards TNBC MDA-MB231 cells. Spirooxindoles 40a, 40b and 40c emerged as the most potent analogues with $\mathrm{IC}_{50}=6.70,6.40$ and $6.70 \mu \mathrm{M}$, respectively. Compounds 40a and 40b induced apoptosis in MDA-MB-231 cells, 40b displayed significant increase in the percent of annexin V-FITC positive apoptotic cells from 1.34 to $44 \%$. Furthermore, spirooxindoles 40b and 40c displayed good inhibitory activity against EGFR $\left(\mathrm{IC}_{50}=120\right.$ and $150 \mathrm{nM}$, respectively). These data established that $40 \mathrm{~b}$ might be a potential lead compound for the development of effective anti-TNBC agents [119].
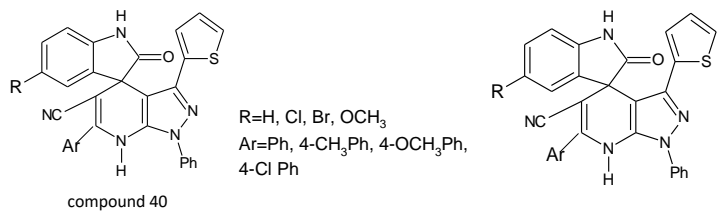

40a: $\mathrm{R}=\mathrm{H}, \mathrm{Ar}=\mathrm{Ph}$ A0b: $\mathrm{R}=\mathrm{Cl}, \mathrm{Ar}=\mathrm{Ph}$ $40 \mathrm{c}=\mathrm{Br}, \mathrm{Ar}=\mathrm{Ph}$,

Patravale et al [120] described facile, sustainable, catalyst-free and biooriented multicomponent method for the synthesis of 2-amino-3-cynospiro $(5 \mathrm{H}$ indeno[1,2-b]pyran-4,3'-indoline)-2'5,-dione using isatin, malononitrile and 1,3indandione and evaluated compounds against breast carcinoma cell lines (MCF7, MDA-MB-435) and normal Vero monkey cell lines. Among all the tested compounds, the bromo- and chloro- substituted indeno-fused spirooxindole derivatives (compounds, $\mathbf{4 1} \& \mathbf{4 2}$ ) were found to show selective potency against the MDA-MB-435 cancer cell lines exhibiting GI $_{50}$ value of 1.8 and $2.1 \mu \mathrm{M}$ respectively. The selected compounds were also screened against the normal Vero monkey cell line, which showed good to excellent selectivity against inhibition of cancer cells.

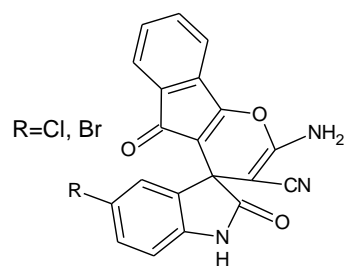

compound 41

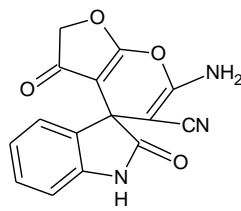

compound 42

\section{CONCLUSIONS}

Due to aforementioned diverse structural features, indole ring is considered as a chief scaffold existing in various bioactive molecules which are known to prevent proliferation and invasion of many cancer cells and these derivatives have arisen as gifted core that need further expansion to obtain more potent and selective cytotoxic agents. It can be concluded that several indole derivatives such as (a) 3-indolylmethylene-2-indolinones derivatives containing pyridine ring display antitumor activity and interesting results were obtained with halogens, methoxy and dimethylamino groups. (b) Bis-indole derivatives were evaluated against various human cancer cell lines and were mainly found to be active against colon (HCT-15, SW-620) cancer cells. (c) (5-((2(hydroxymethyl)-4H-furo[3,2-b]indol-4-yl)methyl)furan-2-yl)methanol was found to exhibit highly selective anticancer activity against NCI-60 human tumor cell lines and significant inhibitory activity against A498 renal cancer cells. (d) Pyrido[3,4-b]indoles displayed SAR with respect to antiproliferative activity. (e) 1-Naphthyl at C-1 combined with methoxy at C-6 (1-naphthyl-6-methoxy-9Hpyrido[3,4-b]indole) provided the best antiproliferative activity. (f) The indole hybridized diazenyl derivatives, Compound $16\left(\mathrm{X}=\mathrm{Y}=\mathrm{R}=\mathrm{R}^{2}=\mathrm{H}, \mathrm{R}^{1}=4-\mathrm{COOH}\right)$ and compound 17 were found to be active against breast cancer cell line and human colon carcinoma cell line having $\mathrm{IC}_{50}$ in the range of 19 $65 \mu \mathrm{g} / \mathrm{ml}$. Further, a range of substituted $1 H$-indole-2,3-diones (isatins) were synthesized and studied for their cytotoxicity against the human monocyte-like histiocytic lymphoma (U937) cell line in vitro. SAR studies indicated $\mathrm{C}_{5}, \mathrm{C}_{6}$, and $\mathrm{C}_{7}$ substitution greatly enhanced activity with some di- and tri-halogenated isatins giving $\mathrm{IC}_{50}$ values $<10 \mu \mathrm{M}$. These results indicate that di- and trisubstituted isatins may be useful leads for anticancer drug development in the future. Additionally, 5 or 7 substituted 3-\{4-(5-mercapto-1,3,4-oxadiazol-2yl)phenylimino -indolin-2-one derivatives were studied for their anticancer activity against HeLa cancer cell lines. Among the synthesized 2-indolinones, compounds with halogen atom (electron withdrawing groups, $\mathrm{F}, \mathrm{Cl}, \mathrm{Br}$ ) at $\mathrm{C} 5$ position showed the most potent activity. Similarly, various Spiro-indole derivatives have been synthesized viz. Spiro [ $3 H$ - indole-3,2'-thiazolidine]2,4'(1H)-diones, Spiro[indolepyranopyrrole], Spiro[pyrrolidine-3,3'-oxindole], Spiro[indole-3,5'-isoxazolidin]-2(1H)-one which show promising anticancer activity. Spiro-indoles, with $\mathrm{C}-3$ as Spiro atom are one of the most important constituent of many drug molecules and can act as precursors for the synthesis of novel bioactive heterocyclic moiety containing varied rings incorporated at $\mathrm{C}$ 3 of indole ring. This gives tremendous scope for the synthesis of novel pharmacodynamic indole heterocycles.

\section{ACKNOWLEDGEMENT}

Authors are thankful to the Head, Department of Chemistry, University of Rajasthan, Jaipur for providing necessary research facilities in the department.

\section{REFERENCES}

1. V. V. Mulwad, B. P. Langi, A.C. Chaskar, Acta Pol Pharm 68, 39, ( 2011).

2. A. Ansari, A. Ali, M Asif, New Journal of Chemistry 41, 16, (2017).

3. M. Asif, Current medicinal chemistry 19, 2984, (2012).

4. S. Biswal, U. Sahoo, S. Sethy, H.K. Kumar, M. Banerjee, Asian J Pharm Clin Res 5, 1, (2012).

5. M. A. Chiacchio, D. Iannazzo, R. Romeo, S. V. Giofrè, L. Legnani, Current medicinal chemistry 26, 7166, (2019). 
6. J. H. Skerritt, and G. A. Johnston, Eur J Pharmacol 89, 193, (1983)

7. R. Elliott, Mayo Clin Proc 76, 511, (2001).

8. P. I. Joyce, D. Rizzi, G. Calo, D. J. Rowbotham and D. G. Lambert, Anesth Analg 95, 1339, (2002).

9. E. Mutschler and H. Derendorf, Med. Pharm Scientific Publishers, Stuttgart, 16, (1995).

10. Guyton and Hall, "Text book of Medical Physiology" Elsevier-Saunders, 7th Ed (2005).

11. L. P. Garrod, Br. Med. J., 1 (5172), 527, (1960).

12. C. H. Dash, Penicillin allergy and the cephalosporins. J Antimicrob Chemother, 1, 107, (1975).

13. E. Goldstein, Am J Med 82, 3, (1987).

14. W. Kingston, J History Med Allied Sci 59, 441 (2004).

15. S. Senapati, A. K. Mahanta, S. Kumar, P. Maiti, Signal transduction and targeted therapy, 3, 1, (2018)

16. V. Mistiaen, Time and the great healer. The history behind the discovery of streptomycin (2002).

17. P. Martins, J. Jesus, S. Santos, L. R. Raposo, C Roma-Rodrigues, P. V. Baptista, A. R. Molecules 20,16852, (2015).

18. S. Kakkar, S. Kumar, B. Narasimhan, S. M. Lim, K. Ramasamy, V. Mani, S. A. Shah, Chemistry Central Journal 12, 96, (2018).

19. A. Kumari, R. K. Singh, Bioorganic chemistry 103021, (2019).

20. S. J. Singh, R. Singla, V. Jaitak, Anti-Cancer Agents in Medicinal Chemistry (Formerly Current Medicinal Chemistry-Anti-Cancer Agents) 16, 160, (2016)

21. M. Z. Zhang, Q. Chen, G. F. Yang, European journal of medicinal chemistry 89, 421, (2015).

22. (a) T. V. Sravanthi, S. L. Manju, European Journal of Pharmaceutical Sciences 91, 1, (2016), (b) S. Dadashpour, S. Emami, European journal of medicinal chemistry, 150, 9, (2018).

23. M. E. Welsch, S. A. Snyder, B.R. Stockwell, Curr Opin Chem Biol 14, 347, (2010).

24. A. de Sa, R. Fernando, E. J. Barreiro, C.A. Manssour Fraga, Mini Rev Med Chem, 9, 782, (2009).

25. B.E. Evans, K.E. Rittle, M.G. Bock, R.M. DiPardo, R.M. Freidinger, W.L. Whitter, G.F. Lundell, D.F. Veber, P.S. Anderson, R.S. Chang, V.J. Lotti, D.J. Cerino, T.B. Chen, P.J. Kling, K.A. Kunkel, J.P. Springer, J. Hirshfiel d, J. Med. Chem., 31, 2235, (1988).

26. S. Verma, Y. S Prabhakar, Current medicinal chemistry. 22, 1603, (2015).

27. D. Sunil, P. R. Kamath, Current topics in medicinal chemistry. 17, 959, (2017).

28. D. L. Nelson, M. M. Cox, Principles of Biochemistry ( $4^{\text {th }}$ Ed.), New York: W.H. Freeman, ISBN 0-7167-4339-6 (2005).

29. C. Won, X. Shen, K. Mashiguchi, Z. Zheng, X. Dai, Y. Cheng, H. Kasahar a, Y. Kamiya, J. Chory, Y. Zhao, Proc Natl Acad Sci U S A 108, 18518, (2011).

30. M.Z. Zhang, N. Mulholland, D. Beattie, D. Irwin, Y.C. Gu, Q. Chen, G. F. Yang, J. Clough, Eur J Med Chem, 63, 22, (2013).

31. H. A. Hamid, A. N. Ramli, M. M. Yusoff, Frontiers in pharmacology 8, 96, (2017).

32. D. P. Mishra, M. A. Khan, D. K. Yadav, A. K. Rawat, R. K. Singh, T. Ahamad, M. K. Hussain, M. Saquib, M. F. Khan, Chemistry Select 3, 8468, (2018).

33. W. Gul, M. T. Hamann, Life sciences 78, 442, (2005).

34. J. W. Blunt, B. R. Copp, R. A. Keyzers, M. H. Munro, M. R. Prinsep, Natural Product Reports 34, 235, (2017)

35. F.-E. Chen, J. Huang, Chem Rev 105, 4671, (2005).

36. E. Stempel, T. Gaich, Accounts of chemical research 49, 2390, (2016).

37. J. Zhou, J. H. Feng, L. Fang, Bioorganic \& medicinal chemistry letters 27, 893 (2017).

38. M. J. Ferreira, A. Paterna, Phytochemistry Reviews 18, 971, (2019).

39. H. Ishikawa, D.A. Colby, D.L. Boger, J Am Chem Soc 130, 420, (2008).

40. M. A. Jordan and L. Wilson, Nat. Rev. Cancer 4, 253, (2004).

41. S. Suzen, Current Organic Chemistry 21, 2068, (2017).

42. L. R. Chen, Y. C. Wang, Y. W. Lin, S. Y. Chou, S. F. Chen, L.T. Liu, Y. T. Wu, C. J. Kuo, T. S. Chen, and S. H. Juang, Bioorg Med Chem Lett 15, 3058, (2005).

43. T. R. Bal, B. Anand, P. Yogeeswari and D. Sriram, Bioorg Med Chem Lett, 15, 4451, (2005)
44. O. Guzel, N. Karali and A. Salman, Bioorg Med Chem, 16, 8976, (2008).

45. S. Smitha, S. N. Pandeya, J. P. Stables, and S. Ganapathy, Sci. Pharm 76, 621, (2008).

46. D. Banerjee, P. Yogeeswari, P. Bhat, A. Thomas, M. Srividya, and D. Sriram, Eur. J. Med. Chem 46, 106, (2011).

47. T. Patel, R. Gaikwad, K. Jain, R. Ganesh, Y. Bobde, B. Ghosh, K. Das, S. Gayen, ChemistrySelect 4, 4478, (2019).

48. K. Kaur, V. Jaitak, Anti-Cancer Agents in Medicinal Chemistry (Formerly Current Medicinal Chemistry-Anti-Cancer Agents), 19, 962, (2019).

49. V. K. Rao, B. S. Chhikara, A. N. Shirazi, R. Tiwari, K. Parang, A. Kumar, Bioorganic \& medicinal chemistry letters 21, 3511, (2011).

50. N. V. Lakshmi, P. Thirumurugan, K. M. Noorulla, P. T. Perumal, Bioorganic \& medicinal chemistry letters 20, 5054 (2010).

51. A. S. Gurkan-Alp, M. Mumcuoglu, C. A. Andac, E. Dayanc, R Cetin-Atalay, E. Buyukbingol, European journal of medicinal chemistry. 58, 346, (2012).

52. S. Safe, S. Papineni, S. Chintharlapalli, Cancer letters 269, 326, (2008).

53. J. R. Weng, C. H. Tsai, S. K. Kulp, C. S. Chen, Cancer letters 262, 153 , (2008).

54. V. P. Garikapaty, B. T. Ashok, Y. G. Chen, A. Mittelman, M. Iatropoulos, R. K. Tiwari, Oncology reports 13, 89, (2005).

55. S. A. Patil, R. Patil, D. D. Miller, Future medicinal chemistry 4, 2085 , (2012).

56. A. Andreani, S. Burnelli, M. Granaiola, A. Leoni, A. Locatelli, R. Morigi, M. Rambaldi, L.Varoli, L. Landi, C. Prata, M. V. Berridge, Journal of medicinal chemistry 51, 4563, (2008).

57. J. Amato, N. Iaccarino, B. Pagano, R. Morigi, A. Locatelli, A. Leoni, M. Rambaldi, P. Zizza, A. Biroccio, E. Novellino, A. Randazzo, Frontiers in chemistry 2, 54, (2014).

58. V. Sharma, R. Kalia, T. Raj, V. K. Gupta, N. Suri, A. K. Saxena, D. Sharma, S. S. Bhella, G. Singh, M. P. Ishar, Acta pharmaceutica Sinica B 2, 32 , (2012).

59. S. H. Zhuang, Y.C. Lin, L.C Chou, M. H. Hsu, H. Y. Lin, C. H. Huang, J C. Lien, S. C. Kuo, L. J. Huang, European journal of medicinal chemistry 66, 466, (2013).

60. S. A. Patil, J. K. Addo, H. Deokar, S. Sun, J. Wang, W. Li, D. P. Suttle, W. Wang, R. Zhang, J. K. Buolamwini, Drug designing: open access 6, (2017)

61. I. Ali, S. D. Mukhtar, M. F. Hsieh, Z. A. Alothman, A. Alwarthan, RSC advances 8, 37905, (2018).

62. M. M. Kamel, M. K. Abdel-hameid, H. B. El-Nassan, E. A. El-Khouly, Medicinal Chemistry 15, 873, (2019).

63. S. Cascioferro, G. Li Petri, B. Parrino, B. El Hassouni, D. Carbone, V. Arizza, U. Perricone, A. Padova, N. Funel, G. J. Peters, G. Cirrincione, Molecules 25, 329, (2020).

64. H. Kaur, J. Singh, B. Narasimhan, BMC chemistry 13, 65, (2019).

65. K. L. Vine, L. Matesic, J. M. Locke, M. Ranson, D. Skropeta, Anti-Cancer Agents in Medicinal Chemistry (Formerly Current Medicinal ChemistryAnti-Cancer Agents) 9, 397, (2009).

66. N. Ristovska, F. Anastasova, M. Stefova, Molbank 2013(2), M798, (2013).

67. P. Pakravan, S. Kashanian, M. M. Khodaei, F. J. Harding, Pharmacological Reports. 65, 313, (2013).

68. R. Jarapula, K. Gangarapu, S. Manda, S. Rekulapally, International journal of medicinal chemistry 2016, (2016).

69. P. K. Shukla, M. P. Singh, R. Patel, Journal of Applied Pharmaceutical Sciences and Research 16 (2018).

70. O. L. Erdman, Journal für Praktische Chemie 19, 321, (1840).

71. A. Laurent, Ann Chim Phy 3, 393, (1840).

72. A. A. Jarrahpour and D. Khalili, Molbank, M437 (2005).

73. K.A.J.A.L Bayati, Tikrit J. Pure Sci, 2, 17, (2012).

74. S. N. Pandeya, P. Yogeeswari, D. Sriram and G. Nath, Bull Chim Farm 137, 321, (1998).

75. M. Sarangapani and V. M. Reddy, Indian J Heterocycl Chem 3, 257, (1994).

76. R. S. Varma and W. L. Nobles J Pharm Sci 64, 881, (1975).

77. S. K. Sridhar, S. N. Pandeya, J. P. Stables and A. Ramesh Eur J Pharm Sci 16, 129, (2002).

78. M. Varma, S. N. Pandeya, K. N. Singh and J. P. Stables Acta Pharm 54, 49, (2004).

79. S. N. Pandeya, D. Sriram, G. Nath and E. De Clercq Acta Helv 74, 11, (1999). 
80. S. N. Pandeya, D. Sriram, G. Nath, and E. De Clercq, Eur J Med Chem 35, 249 (2000)

81. S. N. Pandeya, D. Sriram, G. Nath, and E. De Clercq, Arzneim-Forsch Drug Res 50, 55, (2000)

82. S. P. Singh, S. K. Shukla, and L. P. Awasthi, Curr Sci 52, 766 (1983).

83. S. S. Karki, U. K. Mazumder, M. Gupta, S. Bhattacharya, S. Rathinasamy, and S. Thangavel, Chem Pharm Bull 52, 178, (2004).

84. S. S. Karki, T. Shrikanth, Y. D. Satyanarayana, J. Balzarini, and E. De Clercq, Bioorg Med Chem 15, 6632, (2007).

85. K. C. Joshi, V. N. Pathak, and S. K. Jain, Pharmazie 35(11), 677, (1980).

86. K. C. Joshi, V. N. Pathak, and R. K. Chaturvedi, Pharmazie 41, 634, (1986).

87. R. Jain and M. A. Bansal, Pharmazie 50, 224, (1995).

88. K. L. Vine, J. M. Locke, M. Ranson, S. G. Pyne, J. B. Bremner Bioorganic $\&$ medicinal chemistry $15,931,(2007)$

89. Y. O. Teng, H. Y. Zhao, J. Wang, H. Liu, M. L. Gao, Y. Zhou, K. L. Han, Z. C. Fan Y. M. Zhang, H. Sun, P. Yu, European journal of medicinal chemistry 112, 145, (2016).

90. S. B. KumarM, M. Ravinder, G. Kishore, V. J. Rao, P. Yogeeswari, D. Sriram, Medicinal Chemistry Research 23, 1934, (2014).

91. R. Gudipati, R. N. Anreddy, S. Manda Saudi Pharmaceutical Journal 19, 153, (2011).

92. A. Kamal, Y. V. Srikanth, M. N. Khan, T. B. Shaik, M. Ashraf, Bioorganic \& medicinal chemistry letters 20, 5229, (2010).

93. N. M. Evdokimov, I. V. Magedov, D. McBrayer, A. Kornienko, Bioorganic \& medicinal chemistry letters 26, 1558, (2016).

94. W. M. Eldehna, M. F. Abo-Ashour, A. Nocentini, P. Gratteri, I. H. Eissa, M. Fares, O. E. Ismael, H. A. Ghabbour, M. M. Elaasser, H. A. Abdel-Aziz, C T. Supuran, European journal of medicinal chemistry 139, 250, (2017).

95. A. Nagarsenkar, L. Guntuku, S. D. Guggilapu, S. Gannoju, V. G. Naidu, N. B. Bathini European journal of medicinal chemistry. 124, 782, (2016).

96. H. S. Ibrahim, S. M. Abou-Seri, H. A. Abdel-Aziz, European journal of medicinal chemistry 122, 366, (2016).

97. L. Zhang, F. Chen, J. Wang, Y. Chen, Z. Zhang, Y. Lin, X. Zhu, RSC Advances. 5, 97816, (2015).

98. T. Nasr, S. Bondock, M. Youns, European journal of medicinal chemistry 76, 539, (2014)

99. R. Kakkar, MedChemComm 10, 351, (2019).

100. K. C. Joshi, R. Jain, and P. Chand, Heterocycles, 23, 957, (1985).

101. A. Dandia, R. Singh, H. Sachdeva, R. Gupta, S. Paul, Journal of the Chinese Chemical Society, 50, 273, (2003).

102. A. Nandakumar, P. Thirumurugan, P. T. Perumal, P. Vembu, M. N. Ponnuswamy, P. Ramesh, Bioorganic \& medicinal chemistry letters. $\quad 20$, 4252, (2010).

103. T. H. Kang, K. Matsumoto, M. Tohda, Y. Murakami, H. Takayama, M. Kitajima, N. Aimi, H. Watanabe, European journal of pharmacology 444, 39, (2002).

104. A. A. Patchett, R. P. Nargund, J. R. Tata, M. H. Chen, K. J. Barakat, D. B. Johnston, K. Cheng, W. W. Chan, B. Butler, G. Hickey, Proceedings of the National Academy of Sciences 92, 7001, (1995).

105. R. Misra, R. C. Pandey, J. V. Silverton, Journal of the American Chemical Society 104, 4478, (1982).

106. P. Saraswat, G. Jeyabalan, M. Z. Hassan, M. U. Rahman, N. K. Nyola, Synthetic Communications 46, 1643, (2016).

107. K. C. Joshi, A. Dandia, S. Bhagat, Journal of Fluorine Chemistry 48, 169, (1990)

108. M.S. Islam, H. M. Ghawa, F. F. El-Senduny, A. M. Al-Majid, Y. A. Elshaier, F. A Badria, A. Barakat, Bioorganic chemistry 82, 423, (2019).

109. A. Barakat, M. S. Islam, H. M. Ghawas, A. M. Al-Majid, F. F. El-Senduny, F. A. Badria, Y. A. Elshaier, H. A. Ghabbour, RSC advances 8, 14335, (2018).

110. D. Kaminskyy, D. Khyluk, O. Vasylenko, L. Zaprutko, R. Lesyk, Scientia pharmaceutica. 79, 763, (2011).

111. C. Han, T. Zhang, A. Zhang, D. Wang, W. Shi, J. Tao, Synthesis. 46, 1389, (2014).

112. D. Konyar, C. A. Andac, E. Buyukbingol, Letters in Drug Design \& Discovery 15, 37, (2018).

113. S. R. Yong, A. T. Ung, S. G. Pyne, B. W. Skelton, A. H. White, Tetrahedron. 63, 5579, (2007)
114. A. Barakat, M. S. Islam, H. M. Ghawas, A. M. Al-Majid, F. F. El-Senduny, F. A. Badria, Y. A. Elshaier, H. A. Ghabbour, RSC advances 8, 14335 , (2018).

115. M. S. Islam, H. M. Ghawas, F. F. El-Senduny, A. M. Al-Majid, Y. A Elshaier F. A. Badria, A. Barakat, Bioorganic chemistry 82, 423, (2019).

116. L. Wu, Y. Liu, Y. Li, Molecules 23, 2330, (2018).

117. G. Lotfy, M. M. Said, H. El Sayed, H. El Sayed, A. Al-Dhfyan, Y. M. Aziz, A. Barakat, Bioorganic \& medicinal chemistry 25, 1514, (2017).

118. N. Arumugam, A. I. Almansour, R. S. Kumar, D. M. Al-Thamili, G Periyasami, V. S. Periasamy, J. Athinarayanan, A. A. Alshatwi, S. M. Mahalingam, J. C. Menéndez, Chemistry Central Journal 12, 1, (2018).

119. W. M. Eldehna, D. H. EL-Naggar, A. R. Hamed, H. S. Ibrahim, H. A. Ghabbour, H. A. Abdel-Aziz, Journal of enzyme inhibition and medicinal chemistry, 33, 309, (2018).

120. A. A. Patravale, A. H. Gore, G. B. Kolekar, M. B. Deshmukh, P. B Choudhari, M. S. Bhatia, S. Prabhu, M. D. Jamdhade, M. S. Patole, P. V. Anbhule, Journal of the Taiwan Institute of Chemical Engineers 68, 105, (2016). 